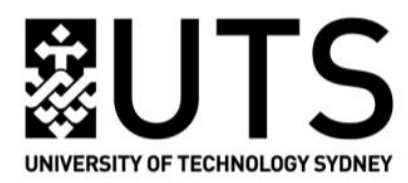

NEW: Emerging Scholars in Australian Indigenous Studies

\title{
Rabbit-Proof Fence: A Critical Analysis
}

\section{Laura Hermannová}

Since the colonisation of Australia, the relationship between western settlers and Aborigines has been characterised by inconsistent policies, ranging from segregation to relocation to assimilation. Yet no event seems to elicit such a profound reaction as the Stolen Generation. While it has only become the product of discussion in recent decades, it is now deeply embedded in Australian consciousness, with a multitude of films, scholarly publications and memoirs inspired by it. One such film is Rabbit-Proof Fence, directed by Phillip Noyce and based on the nonfiction book Follow the Rabbit-Proof Fence by Doris Pilkington Garimara. Set in 1931, the film describes the experience of three half-caste girls, Molly, Gracie and Daisy, who are forcibly removed from their family and community in Jigalong and taken to the Moore River Native Settlement, their consequent escape and three-month journey home. But what are some of the methods utilised to portray the many issues surrounding the Stolen Generation and what are their effects?

One of the first methods employed in the film is the use of juxtapositions. Rabbit-Proof Fence depicts Aboriginal life, represented by Molly and her community, very positively. Molly and her family are seen hunting, playing and laughing together. This makes the practices and laws of western society appear as a destructive imposition and subtly suggests that it is white society that appears to be out of touch with Aboriginal society, instead of the other way around. This works against the idea that Aboriginal half-caste children needed to be saved from their own community with state removal being in their interest. This is further highlighted by Molly, Gracie and Daisy's escape and determined walk home, symbolising a powerful denial of the western policies forced upon them, as well as showing the strength of their connection to Aboriginal culture. This makes it even more devastating knowing how much this connection was severed for those affected by child removal policies.

A further technique is the generalisation of certain aspects, as well as an emphasis on emotional elements (as opposed to strictly factual ones). A prominent example of this is the removal scene. The three girls are aggressively ripped out of their mother's arms, attempting to resist capture, while she screams and pleads for them not to be taken. This scene is clearly designed to highlight the trauma, pain and injustice of separation, but has a further effect, which is both necessary, yet problematic. This scene in particular creates the impression that all removals were like this, aiding the construction of a 'big truth' (Read 2002, p. 54). In 'Clio or Janus', Peter Read argues that the establishment of a more generalised and standard account is usually the first step necessary in order 
to have it secured as part of history, and once this has happened, 'smaller truths' i.e. divergent and different accounts, tend to be recognised (Read 2002, p. 55). In the case of the Stolen Generation however, he makes the point that critics still deny its existence, and use these smaller truths to undermine it, as in the case of Lowitja O'Donoghue (2002, p. 58). This essentially leads to a continued necessity of a more simplistic truth. The film may not be actively working toward Read's notion, but its emotive generalisation of viewpoints certainly aids in consolidating the existence of the Stolen Generation. It could however be argued that it oversimplifies. Heather Goodall, in her article 'Too Early or Not Soon Enough', emphasises the different circumstances children experienced both when they were removed as well as in their settlements and apprenticeships, ranging from 'being seized (...) from stable and happy family homes' to removal from conditions where 'children needed genuine refuge' $(2002$, p.14). She goes on to note that 'these were obviously (...) enormous, multi-dimensional experiences' (2002, p. 14). What is clear, however, is that generalisation is a useful and effective method of polarisation, also employed by Aboriginal activists such as Fred Maynard or Pearl Gibbs, with the aim of abolishing this removal system. Goodall describes their approach of reducing 'their description down to its most stark and simple outlines, stressing what they saw to be its fundamental dangers and injustices, rather than being diverted to the variations which arose from each child's case' (2002, p. 15). Maynard and Gibbs were, however, facing a much more austere political climate, but as mentioned above, the continuing denial of the Stolen Generation today, notably by the former Prime Minister, legitimises a similar approach being employed by this film.

One of the most significant aspects of the film is that it does not shy away from the role that institutionalised racism played in child removal, making it stunningly clear that the aim was to breed out the apparent Aboriginal blood, articulating these sentiments through the figure of A.O. Neville. In and after the 'Bringing Them Home Report', President of the Human Rights Commission Ronald Wilson, as well as organisations such as Link-Up, viewed this child removal as genocide (Attwood 2001, p. 204), although the film stops just shy of using this term. Despite this, the frankness of the film is vital for emphasising the ideology of white supremacy that dominated attitudes to Aborigines throughout colonial history and still seems to be an aspect shied away from in Australian society today, with the former Prime Minister of Australia explicitly stating: 'I didn't believe genocide had taken place, and I still don't' (quoted in Davidson, 2014).

An autobiographical element is included at the end of the film, showing Molly and Daisy recounting their experiences. This is significant for two reasons: firstly, it makes clear that the tale is not removed from reality, and secondly highlights the fact that Molly had to go through the same ordeal later on in life, losing her children in the process (contesting the happy ending of the film). It is this part of the film that really expresses how the government's policies severed the links between family, identity, culture and belonging. Read addresses this, stating that 'perhaps fifty thousand children suffered as a consequence of national policies to desocialise them from their rightful cultural inheritance' (Read 2002, p.57).

The film, in my mind, has one main weakness: portraying Aboriginal child removal as a finished process, despite this is not quite being the case (child removal today being one of the consequence of the Stolen Generation). According to The Guardian, 'state intervention into Aboriginal families has accelerated child removal in the 20 years since the Bringing Them Home report' (Lavarch 
2016). While Kevin Rudd portrayed the Stolen Generation as an historically ended process in his 2008 apology, he has recently warned of the 'emergence of a second stolen generation' (Murphy 2017).

To conclude, 'The Rabbit-Proof Fence' is effective in contributing to Read's notion of a 'big truth', even though it glosses over many other multi-dimensional aspects and experiences that do not fully conform with what it is trying to portray. This could be viewed as problematic, but becomes less so if it is put into conjunction with the fact that the film is presenting only one experience, while at the same time needing to get a complex point across (importantly also to audiences outside of Australia). Its incorporation of autobiographical elements as well as its clear, unapologetic addressal of targeted racism being at the root of child removal, is undermined only by presenting child removal as a closed process, sadly helping solidify an impression that is already rather far-reaching in society.

\section{References}

Attwood, B. 2001, "Learning about the truth'. The stolen generations narrative', in B. Attwood \& F. Magowan (eds), Telling Stories. Indigenous history and memory in Australia and New Zealand, Bridget Williams Books, Wellington, pp. 183-212.

Davidson, H. 2014, 'John Howard: there was no genocide against Indigenous Australians', The Guardian, 22 September, viewed 19 April 2017, https://www.theguardian.com/world/2014/sep/22/john-howard-there-was-no-genocide-againstindigenous-australians.

Goodall, H. 2002, "Too early or not soon enough? Reflections on 'sharing' histories as process not collection”, Australian Historical Studies, Vol. 33, No 118, pp. 7-24.

https://doi.org/10.1080/10314610208596176

Lavarch, M. 2016, 'Australia must act now to prevent a new Stolen Generation tragedy', The Guardian, 8 October, viewed 19 April 2017, https://www.theguardian.com/australianews/2016/oct/08/australia-must-act-now-to-prevent-a-new-stolen-generation-tragedy.

Murphy, K. 2017, 'Indigenous child removal rate risks 'second stolen generation', Kevin Rudd warns', The Guardian, 13 February, viewed 19 April 2017, https://www.theguardian.com/australianews/2017/feb/13/indigenous-child-removal-rate-risks-second-stolen-generation-kevin-rudd-warns.

Rabbit-Proof Fence 2002, motion picture, Becker Entertainment, Australia.

Read, P. 2002, 'Clio or Janus? Historians and the Stolen Generations', Australian Historical Studies, vol. 33, no. 118, pp. 54-60. https://doi.org/10.1080/10314610208596179 